\title{
Ingroup identification, hope and system justification: Testing hypothesis from social identity model of system attitudes (SIMSA) in a sample of LGBTQIA+ individuals
}

\author{
Chiara Bonetti ${ }^{1}$ (D) Francesca Rossi ${ }^{1} \cdot$ Luca Caricati $^{1}$ (D)
}

Accepted: 1 July 2021 / Published online: 13 July 2021

(C) The Author(s) 2021

\begin{abstract}
The social identity model of system attitudes (SIMSA) suggests that system justification among low-status groups can be explained by ingroup identification and the hope for a collective future improvement. In this report, we summarize the results of a cross-sectional investigation concerning the relationship between system justification, hope and identification based on a sample of 200 LGBTQIA+ individuals (identifying themselves as non-normative with respect to gender identity and sexual orientation). The results were supportive of SIMSA expectations and showed that system justification was positively linked to hope for future advancement. Importantly, hope played a key role influencing the relations between ingroup identification and perceived ingroup status: for low-status individuals who had high hope, ingroup identification was positively associated with system justification. Limits are acknowledged.
\end{abstract}

Keywords System justification · Gender identification, SIMSA, Hope · LGBTQIA+

\section{Introduction}

It is common evidence that disadvantaged groups can sometimes justify the system which leads them to a disadvantaged position as much as (or even more than) advantaged groups. The tendency to perceive the existing system as legitimate and fair has been termed system justification (Jost \&Banaji, 1994) and has been observed in both high- and low-status groups (as well as in intermediary-status groups, Caricati \&Owuamalam, 2020; Caricati \&Sollami, 2018). While system justification is congruent with ingroup interest for high-status groups, the system justifying motivation runs counter to interest in disadvantaged groups given that, by justifying the system, they also accept and legitimate their disadvantage (Jost, 2011; Jost et al., 2004; Jost \&Banaji, 1994). System Justification Theory (SJT; Jost \&Banaji, 1994) explains this puzzling evidence by positing the existence of a specific human motivation to perceive the existing social system as just and legitimate and this, in turn, allows people to maintain the belief that

Chiara Bonetti

chiara.bonetti@unipr.it

1 Department of Humanities, Social Sciences and Cultural Industries, University of Parma, b.go Carissimi 10, 43121 Parma, Italy social reality is controllable and relatively certain (Jost, 2011). Thus, according to SJT, low-status group members would justify the existing social system because they are motivated to avoid uncertainty and insecurity, which would arise from the belief that the social arrangement is unjust. This also occurs at the expense of personal and group interests that should be sacrificed in order to justify the system. Accordingly, SJT emphasizes that system justification among the disadvantaged would be most visible when ingroup interests are non-salient (e.g., Jost et al., 2003; Sengupta et al., 2015). Several SJTinspired studies have shown that low-status group members could not overtly dispute the legitimacy of the existing system, although low-status group members appear to justify the system to a lesser extent than high-status groups (e.g., Brandt et al., 2020; Caricati, 2017; Caricati \&Lorenzi-Cioldi, 2012). It is worth noting, however, that some studies have shown that low-status groups could justify the system even more than high-status groups (Henry \&Saul, 2006; Jost et al., 2003; Sengupta et al., 2015).

Recently, an alternative theoretical account has been proposed to explain system justification among the disadvantaged. The Social Identity Model of System Attitudes (SIMSA; Owuamalam et al., 2018, 2019a) is rooted in the Social Identity tradition (Tajfel \&Turner, 1979) and suggests that the disadvantaged might justify the system to satisfy group-based motivation, highlighting the role of the need for 
positive social identity (e.g., ingroup interests) in system justification processes. SIMSA assumes that low-status group members could justify the system because a) social constraints force them to not dispute legitimate and stable social stratification; b) they express ingroup favoritism at the overarching system level, and c) they hope that a fair system would allow for the improvement of the collective social position in the future (Owuamalam et al., 2019b). In this paper we focus on hope-inspired motivation: the more disadvantaged people hold hope for future ingroup advancement, the more they would evaluate the existing system (which allows for this hope) to be just. SIMSA also expects that the relationship between hope and system justification will be stronger for high-identified low-status group members given that hope would serve ingroup interests and then should be more relevant for higher identified members (Owuamalam et al., 2018, 2021). Some research seems to support the assumption that, in some cases, ingroup identification will increase system justification among low-status group members. For example, Owuamalam et al. (2016) showed that system justification increased when low-status group members (university and pre-vocational educational students) were strongly identified with their ingroup, and when they hoped for future ingroup advancement. More recently, Owuamalam et al. (2021), in a pre-registered research, showed that women and feminists who strongly identify with their disadvantaged ingroup tend to justify the system to the extent that they hope for a future improvement of the ingroup.

\section{Aim of the Research}

In this report, we describe the results of a research aiming to test some SIMSA expectations about system justification based on a sample of low-status stigmatized individuals, namely LGBTQIA+. System justification within the LGBTQIA+ population has been occasionally investigated and often these studies have focused on the effect of system justification on wellbeing, internalized stigma and attitudes (e.g., Bahamondes-Correa, 2016; Bettinsoli et al., 2020; Pacilli et al., 2011; Suppes et al., 2019). Thus, LGBTQIA+ appears to be an under-investigated population concerning the way in which they might or might not justify the system. Given that LGBTQIA+ groups face strong and increasing stigmatization as well as ostracism, they seem to be an extraordinarily important population with which to investigate the processes that can lead to perceive the system as just and in particular the SIMSA hope-inspired explanation about system justification. According to SIMSA, we expected that system justification would be stronger for LGBTQIA+ individuals who a) perceived their gender ingroup in a low-status position; b) were strongly identified with their gender ingroup, and c) were confident that status of the ingroup would be improved in the near future. In statistical terms, a three-way interaction between status, group identification and hope was expected.

\section{Method}

\section{Participants and Design}

Using a cross-section design with a web-based questionnaire, we collected data from 227 people via convenience sampling over specific web communities by circulating a link to the questionnaire. We preliminarily obtained consent to publish the link by community administrators. Prior to the start of the research, participants were informed that the research was voluntary, anonymous and that the data would be used in an aggregated manner only and not shared with other parties. Participants also learned that they could leave the research at any time and that by starting the research they consented to participate. Firstly, participants were asked about their sex at birth, their present gender identity and their sexual orientation. Twenty-seven participants were excluded from the analysis because they defined themselves as cis-gender and heterosexuals. The analyzed sample comprised 200 participants $\left(M_{\mathrm{age}}=34.10, S D=12.51,64 \%\right.$ women at birth). Most were lesbian or bisexual self-identified females $(45 \%)$ and gay or pansexual self-identified males (26\%), 18 (9\%) identified themselves as non-binary and eight $(4 \%)$ as transexual or transgender.

\section{Measures}

System justification was measured with the 8-item general system justification scale (Kay \&Jost, 2003) asking participants to indicate their agreement with statements such as "In general, I find society to be fair." This scale has been extensively used to assess system justification in previous research and has shown sufficient reliability (Cronbach's alpha is usually greater than .70$)$. In the present study, reliability was satisfactory and in line with previous research $(\alpha=$.78).

Gender identification was measured with five items adapted from Schmitt et al. (2002) and Owuamalam et al. (2021) and referred to the gender group. Items asked participants to indicate the extent to which they agreed with statements such as "I like being a member of my gender group". These items have been widely used in previous research showing good reliability (alpha greater than .80, see e.g., Schmitt et al., 2002). Also in the present work, the scale was reliable $(\alpha=.89)$.

Hope for future ingroup advancement was measured with three items asking participants to indicate their agreement with statements such as "I am hopeful that LGBTQIA+ groups will be treated fairly within a few years." These items were taken and adapted from Owuamalam et al. (2021). In line with 
previous work, in the present research the scale was reliable $(\alpha=.79)$.

Perception of ingroup status was measured by a single item asking participants to indicate the "level of prestige most people would attribute to your gender group" (1=very low prestige; $10=$ very high prestige).

If not otherwise specified, measures were on an 8-point Likert-type scale ( $1=$ strongly disagree, $8=$ strongly agree). See supplementary materials for the full list of items.

\section{Results}

Preliminarily, we tested whether items would measure different constructs through confirmative factor analysis in which three latent traits (i.e., system justification, gender identification and hope) as measured by their intended items were considered. Results indicated that the model had good fit, $\mathrm{CFI}=.948$, TLI=.937, RMSEA $=.057, p=.223$, 90\% CI [.041, .072] and all items were significantly measured by the intended latent dimension (all $p \mathrm{~s}<.001$ ). This confirms the fact that measures were reliable and did not overlap with one another. Accordingly, zero-order correlations (see Table 1) revealed that variables were correlated one to another with weak magnitudes thus indicating no collinearity concerns. As indicated and congruently with SIMSA expectations, hope was positively correlated with system justification. Moreover, system justification was positively correlated with status. Finally, hope was positively correlated with status.

No variable had both kurtosis and skew greater than $|1|$ suggesting no distribution concerns (e.g., Gravetter \&Wallnau, 2014).

Hypotheses were tested with regression analysis with 5000 bootstrap resamples to better accommodate standard error estimation and $95 \%$ confidence intervals. Predictors were grandmean centered before being entered in the analysis. In order to detect the reached power, a Monte Carlo simulation was performed considering estimates as starting values and 5000 replications with a sample size of 200 . All analyses were conducted with the $\mathrm{R}$ software ( $\mathrm{R}$ Core Team, 2020). Results are shown in Table 2 and analysis yielded only two significant effects for which the estimated power was higher than $80 \%$. More precisely, hope in future advancement was positively associated with system justification, while status and identification were not. Moreover, the expected three-way interaction was significant. Decomposition of the three-way interaction (see Fig. 1) indicated that the relationship between identification and system justification was similar for both high and low status when hope was low, $\Delta b=-0.066$, se=0.097, $p=.498$. When, instead, hope was high, ingroup identification was positively associated with system justification for low-status members, but negatively for high-status members, $\Delta b=0.368$, $s e=0.105, p=<.001$. No other effect was significant.

\section{Discussion}

The research described in this report aimed to test some predictions from SIMSA about the relationship between ingroup identification, hope for future advancement and system justification in a low-status group of LGBTQIA+ individuals. To the best of our knowledge, this is the first attempt to investigate social identity processes linked to the justification of the existing social system within a sample of stigmatized individuals. Results are supportive of the SIMSA account and indicate that the association between low-status ingroup identification and system justification is positive when the disadvantaged hope for a future advancement of the ingroup (Owuamalam et al., 2021). Thus, low-status individuals who hoped for future change justified the system when they were strongly identified with their disadvantaged position (i.e., ingroup interests were high). On the contrary, high-status individuals who hoped for future change justified the system when they were weakly, rather than strongly, identified with
Table 1 Descriptive statistics and zero-order correlations between considered variables

\begin{tabular}{lllll}
\hline & System justification & Gender identification & Hope & Status \\
\hline System justification & .78 & -.06 & $.18^{* *}$ & $.16^{*}$ \\
Gender identification & & .89 & .09 & .02 \\
Hope & & & .79 & $.28^{* *}$ \\
Status & 2.67 & 6.30 & & - \\
$M$ & 1.06 & 1.70 & 3.95 & 5.10 \\
$S D$ & .81 & -0.91 & 1.74 & 2.54 \\
Skew & 1.05 & 0.18 & 0.24 & 0.20 \\
Kurtosis & $1-8$ & $1-8$ & -0.68 & -0.86 \\
Range & & & $1-8$ & $1-10$ \\
\hline
\end{tabular}

$* p<.05 ; * * p<.01$

Cronbach's alpha on the diagonal. $N=200$ 
Table 2 Results from regression analysis on system justification

\begin{tabular}{llllll}
\hline & $b$ & $s e$ (bootstrapped) & $95 \% \mathrm{CI}$ (bootstrapped) & $\beta$ & Pwr (Cvrg) \\
\hline Identification & -0.063 & 0.05 & {$[-0.14 ; 0.06]$} & -.101 & $.341(.938)$ \\
Hope & $0.123 * *$ & 0.05 & {$[0.03 ; 0.23]$} & .202 & $.805(.936)$ \\
Status & 0.054 & 0.03 & {$[-0.01 ; 0.11]$} & .130 & $.471(.938)$ \\
IDxHO & -0.010 & 0.03 & {$[-0.07 ; 0.06]$} & -.030 & $.087(.936)$ \\
IDxST & -0.030 & 0.02 & {$[-0.06 ; 0.02]$} & -.131 & $.492(.938)$ \\
HOxST & 0.006 & 0.02 & {$[-0.03 ; 0.04]$} & .030 & $.087(.940)$ \\
IDxSTxHO & $-0.025^{*}$ & 0.01 & {$[-0.05 ;-0.01]$} & -.253 & $.964(.938)$ \\
\hline
\end{tabular}

$N=200 . * * p<.01 ; * p<.05$

ID Identification, HO Hope, ST Status, Pwr Power, Cvrg Coverage the ingroup (i.e., ingroup interests are low). On the whole, these results seem to be congruent with SIMSA assumption that system justification can be driven by ingroup interests (i.e., ingroup identification) and hope-inspired expectations. The latter influence the perception of the system as fair allowing the disadvantaged to hope for the ingroup's future advancement. These results also contribute to the debate as to whether ingroup interests are implied in system justification. While SJT assumes that ingroup identification will work as a factor reducing the likelihood that low-status group members justify the system as ingroup interests are incongruent with system interests (Jost, 2011, 2019; Jost et al., 2019), SIMSA assumes that ingroup interests should be salient for making low-status group members likelier to justify the system in light of hope for future ingroup advancement (Owuamalam et al., 2019b). Our results seem to support the latter expectation by indicating that even in a strongly stigmatized group, system justification is affected by the social disadvantage that individuals attribute to their ingroup, the hope they have in future ingroup advancement as well as the strength to which they feel identified with their ingroup. This suggests that low-status group members might justify the system which leads them to a (even strongly) disadvantaged position to the extent they perceive the legitimacy of the system as a potential vehicle for social change (Owuamalam et al., 2017, 2019a). That is not to say, of course, that low-status group members always justify the system because they hope for a future improvement for the ingroup. Rather, this remains only one of the possible ways in which inequality could be actively maintained by the disadvantaged. In this sense, we believe that our results could add further knowledge to the many facets through which system justification could appear among disadvantaged group members.

\section{Limitations and Future Research}

This work has some limitations which must be taken into account. One of these is linked to its cross-sectional design that prevents us to infer causal relationships between variables. This might also be linked to increased common method biases (Podsakoff et al., 2003) which, in turn, might have an inflated association between variables. Although the correlations among variables were relatively low, we must consider that results could have been somewhat affected by common method bias. Furthermore, the specific sample that has been investigated might limit the generalizability of the results.
Fig. 1 Three-way interaction between hope, perceived ingroup status and ingroup identification on system justification

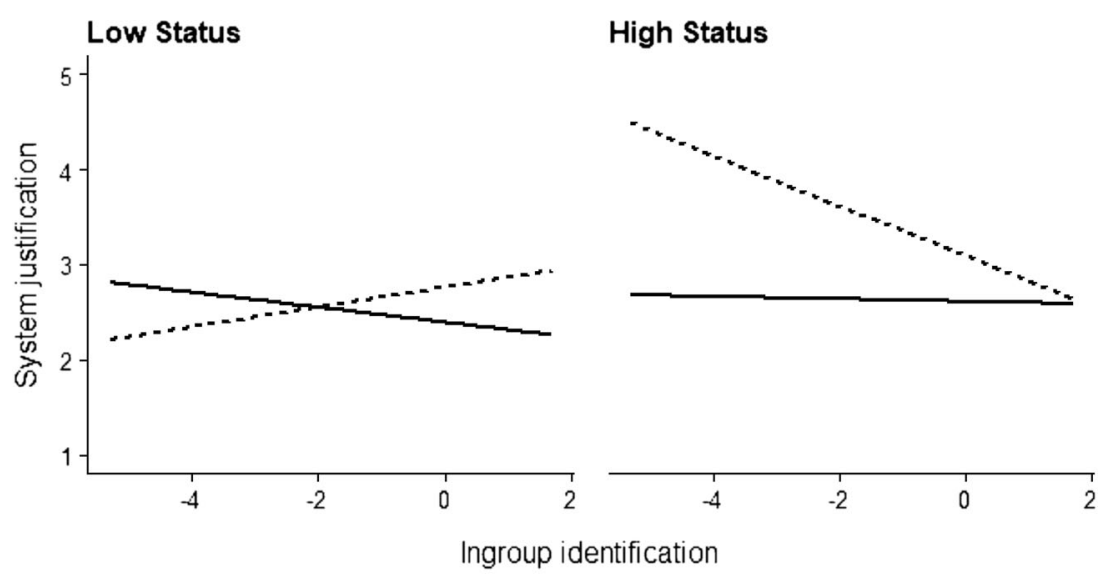

Hope - Low hope -.. High hope 
Although our results come from a stigmatized sample, there is no certainty that other stigmatized or disadvantaged groups would not produce partially or completely different results.

Future research is warranted to analyze these processes in depth. In particular, considering different disadvantaged groups could help to increase our understanding of system justification processes. Moreover, experimental design manipulating status and hope could be used to disentangle possible overlaps between group identification, status and hope.

Supplementary Information The online version contains supplementary material available at https://doi.org/10.1007/s12144-021-02062-2.

Acknowledgments Authors would like to thank Francesco Cavaggioni for his help in language editing and revision.

Funding Open access funding provided by Università degli Studi di Parma within the CRUI-CARE Agreement.

Data Availability The datasets generated during and/or analyzed during the current study are available from the corresponding author on reasonable request.

\section{Declarations}

Conflict of Interest The authors have no potential conflict of interest pertaining to this paper.

Ethical Approval All procedures performed in studies involving human participants were in accordance with the ethical standards of the institutional and/or national research committee and with the 1964 Helsinki declaration and its later amendments or comparable ethical standards.

Open Access This article is licensed under a Creative Commons Attribution 4.0 International License, which permits use, sharing, adaptation, distribution and reproduction in any medium or format, as long as you give appropriate credit to the original author(s) and the source, provide a link to the Creative Commons licence, and indicate if changes were made. The images or other third party material in this article are included in the article's Creative Commons licence, unless indicated otherwise in a credit line to the material. If material is not included in the article's Creative Commons licence and your intended use is not permitted by statutory regulation or exceeds the permitted use, you will need to obtain permission directly from the copyright holder. To view a copy of this licence, visit http://creativecommons.org/licenses/by/4.0/.

\section{References}

Bahamondes-Correa, J. (2016). System Justification's opposite effects on psychological wellbeing: Testing a moderated mediation model in a gay men and lesbian sample in Chile. Journal of Homosexuality, 63(11), 1537-1555. https://doi.org/10.1080/00918369.2016. 1223351.

Bettinsoli, M. L., Suppes, A., \&Napier, J. L. (2020). Predictors of attitudes toward gay men and lesbian women in 23 countries. Social Psychological and Personality Science, 11(5), 697-708. https://doi. org/10.1177/1948550619887785.
Brandt, M. J., Kuppens, T., Spears, R., Andrighetto, L., Autin, F., Babincak, P., Badea, C., Bae, J., Batruch, A., Becker, J. C., Bocian, K., Bodroža, B., Bourguignon, D., Bukowski, M., Butera, F., Butler, S. E., Chryssochoou, X., Conway, P., Crawford, J. T., Croizet, J. C., Lemus, S., Degner, J., Dragon, P., Durante, F., Easterbrook, M. J., Essien, I., Forgas, J. P., González, R., Graf, S., Halama, P., Han, G., Hong, R. Y., Houdek, P., Igou, E. R., Inbar, Y., Jetten, J., Jimenez Leal, W., Jiménez-Moya, G., Karunagharan, J. K., Kende, A., Korzh, M., Laham, S. M., Lammers, J., Lim, L., Manstead, A. S. R., Međedović, J., Melton, Z. J., Motyl, M., Ntani, S., Owuamalam, C. K., Peker, M., Platow, M. J., Prims, J. P., Reyna, C., Rubin, M., Saab, R., Sankaran, S., Shepherd, L., Sibley, C. G., Sobkow, A., Spruyt, B., Stroebaek, P., Sümer, N., Sweetman, J., Teixeira, C. P., Toma, C., Ujhelyi, A., Toorn, J., Hiel, A., Vásquez-Echeverría, A., Vazquez, A., Vianello, M., Vranka, M., Yzerbyt, V., \&Zimmerman, J. L. (2020). Subjective status and perceived legitimacy across countries. European Journal of Social Psychology, 50(5), 921-942. https://doi.org/10. 1002/ejsp.2694.

Caricati, L. (2017). Testing the status-legitimacy hypothesis: A multilevel modeling approach to the perception of legitimacy in income distribution in 36 nations. Journal of Social Psychology, 157(5), 532540. https://doi.org/10.1080/00224545.2016.1242472.

Caricati, L., \&Lorenzi-Cioldi, F. (2012). Does status matter? Testing hypotheses from strong form of system justification theory. Revue Internationale de Psychologie Sociale, 25(1), 67-95.

Caricati, L., \&Owuamalam, C. K. (2020). System justification among the disadvantaged: A triadic social stratification perspective. Frontiers in Psychology, 11, 40. https://doi.org/10.3389/fpsyg.2020.00040.

Caricati, L., \&Sollami, A. (2018). Contrasting explanations for statuslegitimacy effects based on system justification theory and social identity theory. Journal of Theoretical Social Psychology, 2(1), 13-25. https://doi.org/10.1002/jts5.15.

Gravetter, F. J., \& Wallnau, L. B. (2014). Essentials of statistics for the behavioral sciences (8th ed.). Wadsworth Cancage Learning.

Henry, P. J., \&Saul, A. (2006). The development of system justification in the developing world. Social Justice Research, 19(3), 365-378. https://doi.org/10.1007/s11211-006-0012-x.

Jost, J. T. (2011). System justification theory as compliment, complement, and corrective to theories of social identification and social dominance. In D. Dunning (Ed.), Social Motivation (pp. 223-263). Psychology Press. https://doi.org/10.4324/9780203833995.

Jost, J. T. (2019). A quarter century of system justification theory: Questions, answers, criticisms, and societal applications. British Journal of Social Psychology, 58(2), 263-314. https://doi.org/10. 1111/bjso.12297.

Jost, J. T., \&Banaji, M. R. (1994). The role of stereotyping in systemjustification and the production of false consciousness. British Journal of Social Psychology, 33(1), 1-27. https://doi.org/10.1111/ j.2044-8309.1994.tb01008.x.

Jost, J. T., Pelham, B. W., Sheldon, O., \&Sullivan, B. N. (2003). Social inequality and the reduction of ideological dissonance on behalf of the system: Evidence of enhanced system justification among the disadvantaged. European Journal of Social Psychology, 33(1), 1336. https://doi.org/10.1002/ejsp.127.

Jost, J. T., Banaji, M. R., \&Nosek, B. A. (2004). A decade of system justification theory: Accumulated evidence of conscious and unconscious bolstering of the status quo. Political Psychology, 25(6), 881919. https://doi.org/10.1111/j.1467-9221.2004.00402.x.

Jost, J. T., Badaan, V., Goudarzi, S., Hoffarth, M., \&Mogami, M. (2019). The future of system justification theory. British Journal of Social Psychology, 58(2), 382-392. https://doi.org/10.1111/bjso.12309.

Kay, A. C., \&Jost, J. T. (2003). Complementary justice: Effects of "poor but happy" and "poor but honest" stereotype exemplars on system justification and implicit activation of the justice motive. Journal of 
Personality and Social Psychology, 85(5), 823-837. https://doi.org/ 10.1037/0022-3514.85.5.823.

Owuamalam, C. K., Rubin, M., \&Issmer, C. (2016). Reactions to group devaluation and social inequality: A comparison of social identity and system justification predictions. Cogent Psychology, 3(1), 1188442. https://doi.org/10.1080/23311908.2016.1188442.

Owuamalam, C. K., Rubin, M., Spears, R., \&Weerabangsa, M. M. (2017). Why do people from low-status groups support class systems that disadvantage them? A test of two mainstream explanations in Malaysia and Australia. Journal of Social Issues, 73(1), 80-98. https://doi.org/10.1111/josi.12205.

Owuamalam, C. K., Rubin, M., \&Spears, R. (2018). Addressing evidential and theoretical inconsistencies in system-justification theory with a social identity model of system attitudes. Current Directions in Psychological Science, 27(2), 91-96. https://doi.org/ 10.1177/0963721417737136.

Owuamalam, C. K., Rubin, M., \&Spears, R. (2019a). Revisiting 25 years of system motivation explanation for system justification from the perspective of social identity model of system attitudes. British Journal of Social Psychology, 58(2), 362-381. https://doi.org/10. 1111/bjso.12285.

Owuamalam, C. K., Rubin, M., \&Spears, R. (2019b). Is a system motive really necessary to explain the system justification effect? A response to Jost (2019) and Jost, Badaan, Goudarzi, Hoffarth, and Mogami (2019). British Journal of Social Psychology, 58(2), 393409. https://doi.org/10.1111/bjso.12323.

Owuamalam, C. K., Caricati, L., Rubin, M., Matos, A. S., \&Spears, R. (2021). Why do women support socio-economic systems that disadvantage them? A registered test of system justification- and social identity-inspired hope explanations. European Journal of Social Psychology. https://doi.org/10.1002/ejsp.2754.

Pacilli, M. G., Taurino, A., Jost, J. T., \&van der Toorn, J. (2011). System justification, right-wing conservatism, and internalized homophobia: Gay and lesbian attitudes toward same-sex parenting in Italy. Sex Roles, 65(7), 580-595. https://doi.org/10.1007/s11199011-9969-5.

Podsakoff, P. M., MacKenzie, S. B., Lee, J. Y., \&Podsakoff, N. P. (2003). Common method biases in behavioral research: A critical review of the literature and recommended remedies. Journal of Applied Psychology, 88(5), 879-903. https://doi.org/10.1037/0021-9010. 88.5.879.

R Core Team. (2020). R: A language and environment for statistical computing. Vienna, Austria. https://www.r-project.org/.

Schmitt, M. T., Branscombe, N. R., Kobrynowicz, D., \&Owen, S. (2002). Perceiving discrimination against one's gender group has different implications for well-being in women and men. Personality and Social Psychology Bulletin, 28, 197-210. https://doi.org/10.1177/ 0146167202282006.

Sengupta, N. K., Osborne, D., \&Sibley, C. G. (2015). The statuslegitimacy hypothesis revisited: Ethnic-group differences in general and dimension-specific legitimacy. British Journal of Social Psychology, 54(2), 324-340. https://doi.org/10.1111/bjso.12080.

Suppes, A., Napier, J. L., \&van der Toorn, J. (2019). The palliative effects of system justification on the health and happiness of lesbian, gay, bisexual, and transgender individuals. Personality and Social Psychology Bulletin, 45, 372-388. https://doi.org/10.1177/ 0146167218785156.

Tajfel, H., \&Turner, J. C. (1979). An intergrative theory of intergroup conflict. In G. Austin \&S. Worchel (Eds.), The social psychology of intergroup relations (pp. 33-47). Brooks/Cole.

Publisher's Note Springer Nature remains neutral with regard to jurisdictional claims in published maps and institutional affiliations. 